\title{
UNTANGLING THE REQUIREMENT OF GOOD FAITH IN THE DERIVATIVE ACTION IN COMPANY LAW (Part 2)
}

\author{
Maleka Femida Cassim \\ MBBCh (cum laude) LLB (cum laude) LLM (cum \\ laude) $P h D$ \\ Associate Professor, Department of Mercantile \\ Law, University of Pretoria
}

SUMMARY

A crucial prerequisite for a derivative action is that the applicant must be acting in good faith in terms of section 165(5)(b)(i) of the Companies Act 71 of 2008 in order to obtain the leave of the court to bring the proposed derivative action. Both the Supreme Court of Appeal and the High Court have recently made important pronouncements of legal principle on the approach that the courts would take to the determination of good faith for the purposes of the statutory derivative action under section 165 of the Companies Act. These judicial findings relate not only to the complex issue of how to prove good faith but also to the meaning and content of the requirement of good faith. The courts have now reached a crossroads in delineating the content of good faith and how it is to be proved. This two-part series of articles critically evaluates these judicial pronouncements. While the focus of these articles is mainly on the tangled requirement of good faith, relevant judicial findings on the other prerequisites for a derivative action under section 165(5)(b) read with (7) and (8) of the Companies Act are also discussed. A comparative approach is adopted which takes into account the jurisprudence developed in Australia, Canada and Singapore. The first article in this series of two articles discussed the test of good faith. This article focuses on the proof of good faith.

\section{INTRODUCTION}

The South African courts have now reached a turning point in delineating the test of good faith and how it is to be proved for the purposes of the statutory derivative action contained in section 165 of the Companies Act 71 of 2008 (hereinafter "the Act"). In order to be granted the leave of the court to institute a derivative action on behalf of a wronged company, the applicant must prove inter alia that he or she is acting in good faith in terms of section $165(5)(b)$ (i) of the Act. The proof of good faith is undoubtedly a challenging issue, depending as it does on the individual's subjective state of mind. It is telling that the High Court and the Supreme Court of Appeal have differed not only on the fundamental test of good faith and its constitutive elements but also on the intricate question of how good faith is to be proved. It is 
crucial at this juncture for the courts to swiftly unscramble the conundrum of good faith. While the first article in this series of two articles discussed the test of good faith, this article focuses on the proof of good faith. Paragraph 2 below considers the divergent approaches adopted by the High Court and the Supreme Court of Appeal to the problem of proof of good faith, followed by suggestions in Paragraph 3 as to how an applicant is to prove his or her good faith for the purposes of the statutory derivative action. A comparative approach is adopted which takes into account the Australian, Canadian and Singapore law.

\section{PROOF OF GOOD FAITH}

As submitted in the first article in this two-part series of articles, the courts' enquiry into the good faith of an applicant who seeks leave to bring a derivative action in terms of section 165(5)(b)(i) of the Act must, as submitted in Part 1 of this article, be a two-part enquiry involving two interrelated elements:

(i) first, the applicant must honestly believe that a good cause of action exists and that it has a reasonable prospect of success (referred to as "honest belief"); and

(ii) secondly, the applicant must not be seeking to bring the derivative action for a collateral purpose, i.e. the applicant's dominant purpose in bringing the application under section 165(5) must be to protect the legal interests of the company, and not to promote his or her own personal or private purposes.

It is vital for the South African courts to categorically accept, on the basis of deep-rooted legal principles as well as on policy grounds, ${ }^{1}$ that the aspect of collateral purpose must be a fundamental part of the enquiry into good faith under section 165(5)(b)(i) of the Act. Insofar as the South African High Courts $^{2}$ have consistently adopted the classic two-part test of good faith, the approach of the High Courts is, with respect, to be favoured over the truncated test of good faith recently proposed by the Supreme Court of Appeal in Mbethe $v$ United Manganese of Kalahari (Pty) $L t d^{3} .^{3}$ The Supreme Court of Appeal purported to wipe out the element of collateral purpose as a self-standing part of the good faith enquiry, which would serve only to emaciate the requirement of good faith. Fortunately, however, this was an obiter dictum of the Supreme Court of Appeal and is thus not binding on future courts although it could be persuasive authority. ${ }^{4}$

Directly as a result of the conflicting tests of good faith proposed by the court a quo and the Supreme Court of Appeal in the United Manganese case, the two courts also diverged fundamentally on the issue of proof of good faith. While both the court a quo and the Supreme Court of Appeal

\footnotetext{
See further Part 1 of this article, particularly Par 3 and 31 .

2 Mbethe v United Manganese of Kalahari (Pty) Ltd 2016 (5) SA 414 (GJ); Mouritzen v Greystone Enterprises (Pty) Ltd 2012 (5) SA 74.

32017 (6) SA 409 (SCA) par 11 (hereinafter "the United Manganese case"). See further Part 1 of this article.

4 See further Par 3 and 31 of Part 1 of this article.
} 
accepted that the onus rests on the applicant to satisfy the court, on a balance of probabilities, of his or her good faith, ${ }^{5}$ the two courts differed fundamentally on what exactly the applicant must prove in order to establish good faith. The court a quo found that: ${ }^{6}$

"the applicant seeking relief under the subsection bears the onus to discharge both elements of good faith, including that the application has not been brought for a collateral purpose. There is no onus on the respondent to establish this."

In sharp contrast, the Supreme Court of Appeal declared as follows: ${ }^{7}$

"[t]he court a quo ... erred in concluding that an applicant in terms of section $165(5)$ of the Act bore an onus of proving the absence of a collateral purpose, as a self-standing requirement of the good faith enquiry".

It is submitted that since the facet of collateral purpose is a fundamental part of the test of good faith, ${ }^{8}$ the onus must fall on the applicant under section 165(5)(b)(i) to prove, first, his or her honest belief and, secondly, the absence of a collateral purpose in order to establish his or her good faith. The conundrum, though, is how an applicant is to prove positively the absence of a collateral purpose on his or her part. It seems that it perhaps was the difficulty of how one is to prove the absence of a collateral purpose that drove the Supreme Court of Appeal to make its unfortunate finding that the issue of collateral purpose is not part of good faith under section $165(5)(b)(i)$ of the Act. ${ }^{9}$ Certainly, in the context of the fiduciary duty of directors to exercise their powers for a proper purpose, the onus does not fall on the director to prove the absence of a collateral purpose on his or her part; ${ }^{10}$ the onus of proving a collateral purpose rests instead on the person who alleges it.

The proof of good faith undoubtedly presents challenges. The duty of good faith is a subjective one, in that the vital issue is the applicant's state of mind. ${ }^{11}$ Good faith thus requires an inquiry into the subjective aspects of the individual's state of mind. The honest belief of the applicant and his or her intentions, motivations and purposes in seeking leave for a derivative action obviously are matters residing in his or her own mind, which no court can

5 Mbethe $v$ United Manganese of Kalahari (Pty) Ltd 2017 (6) SA 409 (SCA) par 12; Mbethe $v$ United Manganese of Kalahari (Pty) Ltd 2016 (5) SA 414 (GJ) par 82; M F Cassim "The Statutory Derivative Action under the Companies Act of 2008: The Role of Good Faith" 20133 SALJ 496 521; M F Cassim The New Derivative Action under the Companies Act: Guidelines for Judicial Discretion (2016) 51.

Par 169

Par 11.

See further Part 1 of this article, Par 3.

See par 10, in which the Supreme Court of Appeal stated that "[t]he dispute concerned the elevation of the absence of a collateral purpose to the status of an element or criteria of the good faith requirement, to be proved by an applicant as part of the substantive onus relating to good faith".

10 Re Coalport China Co (1895) 2 Ch 404; Charles Forte Investments Ltd v Amanda [1964] 1 Ch 240.

11 Regentcrest plc v Cohen [2001] 1 BCLC 80. 
see into. By what means is the applicant's state of mind to be proved and what type of evidence is required? ${ }^{12}$

\section{Proof of honest belief}

Regarding the first element of the good faith enquiry, namely that the applicant must honestly believe that the company has a good cause of action with a reasonable prospect of success (referred to as "honest belief"), the question is not whether, viewed objectively by the court, the company has, in fact, a good cause of action with a reasonable prospect of success; nor is the question whether the court, had it been in the position of the applicant at the relevant time, might have believed differently. Rather the question is whether the applicant him- or herself honestly believed that the company had a good cause of action with a reasonable prospect of success. The issue is as to the applicant's state of mind $^{13}$ and whether the applicant honestly believed in the viability of the cause of action. ${ }^{14}$

Honesty is, of course, a largely subjective matter. However, there are limits to the subjective test. The courts will not unreservedly accept a bold declaration by an applicant that he or she is acting in good faith if the evidence and the facts do not support the applicant's assertion. The courts may draw inferences concerning the applicant's state of mind from the evidence. $^{15}$ If there are no reasonable grounds for the applicant's belief that the company has a viable cause of action, this may be the basis for finding that the applicant lacks good faith. ${ }^{16}$ The fact that the applicant's alleged belief is unreasonable may provide evidence that it is not in fact honestly held. ${ }^{17}$ It is notable, however, that the objective considerations do not relate to whether the claim is (regardless of the applicant's belief) legally viable, but whether the applicant honestly believes the claim to be legally viable. ${ }^{18}$

Nonetheless, a major step towards showing an honest belief for the purposes of section $165(5)(b)(i)$ is whether there is a serious question to be tried in terms of section 165(5)(b)(ii). Though the satisfaction of the second leave requirement in section $165(5)$ (b)(ii) will by no means be conclusive evidence that the applicant has an honest belief that there is a good cause of action with a reasonable prospect of success, the presence of a serious question to be tried will be of importance in showing such honest belief. As

12 See the discussion of the court a quo in Mbethe $v$ United Manganese of Kalahari (Pty) Ltd 2016 (5) SA 414 (GJ) par 172 quoting M F Cassim 20133 SALJ 521.

13 See eg, Regentcrest plc $v$ Cohen supra.

14 See eg, Extrasure Travel Insurances Ltd v Scattergood [2003] 1 BCLC 598 (ChD).

15 Mbethe $v$ United Manganese of Kalahari (Pty) Ltd 2017 (6) SA 409 (SCA) par 20; see eg, Regentcrest plc $v$ Cohen supra.

16 Mbethe $v$ United Manganese of Kalahari (Pty) Ltd 2017 (6) SA 409 (SCA) par 21; R v Myers 1948 (1) SA 375 (A); see the discussion of the court a quo in Mbethe $v$ United Manganese of Kalahari (Pty) Ltd 2016 (5) SA 414 (GJ) par 172 quoting the views of M F Cassim 20133 SALJ 521; F H I Cassim in F H I Cassim (ed) Contemporary Company Law 2ed (2012) 524 525; Shuttleworth $v$ Cox Brothers and Co (Maidenhead) Ltd [1926] All ER 498 (CA). See also in Australian Law Swansson v R A Pratt Properties Pty Ltd (2002) 42 ACSR 313 par 36; Maher $v$ Honeysett and Maher Electrical Contractors Pty Ltd [2005] NSWSC 859; Fiduciary Ltd v Morningstar Research Pty Limited [2005] NSWSC 442.

17 Extrasure Travel Insurances Ltd $v$ Scattergood supra.

18 Regentcrest plc $v$ Cohen supra. 
so lucidly proclaimed in the Australian case Maher $v$ Honeysett and Maher Electrical Contractors Pty Ltd: $:^{19}$

"the actual existence of the matter [in which] honest belief ... is required is a

firm basis for an inference that there is an honest belief in its existence".

On the other hand, the absence of a serious question to be tried may lead a court to conclude that the applicant had no reasonable grounds for believing that there was a good cause of action; the court may thus infer from this that there was no honest belief and thus no good faith on the part of the applicant.

It is useful to consider the principles stemming from Australian law and to some extent Canadian law, to determine how the South African provision on good faith should be applied. The South African legislature has borrowed heavily from the Australian statutory derivative action and also to some extent from the Canadian version. ${ }^{20}$ The applicant in Australian law, like his or her South African counterpart, bears the onus of proof of satisfying the court on a balance of probabilities of his or her good faith ${ }^{21}$ - contrary to the erroneous statement of the court a quo in the United Manganese case that "the Australian courts apply a less stringent test" than proof on a balance of probabilities. $^{22}$

Significantly, in Australian law, there is no particular type of evidence or no particular means by which to prove the applicant's state of mind or honest belief. Applicants rarely know whether a good cause of action exists or what its prospects of success are, and are generally dependent on the advice of legal counsel. ${ }^{23}$ Accordingly, a sworn statement of the applicant's good faith would usually carry little weight. As stated in Hannon v Doyle, ${ }^{24}$ for instance:

"As to the first aspect [of good faith i.e. honest belief,] it is not necessary that the applicant for leave under section 237 actually say, as part of a sworn statement, that he or she believes in the existence of a good cause of action with reasonable prospects of success. Inferences can be drawn from the nature and circumstances of the case sought to be brought and the diligence with which the applicant asserts it”.

Thus, "the objective facts and circumstances will speak louder than the applicant's words." 25

19 Supra par 36; see also Goozee v Graphic World Group Holdings Pty Limited [2002] NSWSC 640 par 57.

20 See the decision of the court a quo in Mbethe $v$ United Manganese of Kalahari (Pty) Ltd supra fn 2 above par 154; M F Cassim in F H I Cassim Contemporary Company Law 785; M F Cassim The New Derivative Action under the Companies Act: Guidelines for Judicial Discretion 32-34. See Canada Business Corporations Act, 1985, s 238-242; Australian Corporations Act, 2001, s 236-242.

21 Cannon Street Pty Ltd v Karedis [2004] QSC 104 par 178; Swansson v R A Pratt Properties Pty Ltd supra par 26; South Johnstone Mill Ltd v Dennis and Scales [2007] FCA 1448 (FCA) par 68; Chahwan v Euphoric Pty Ltd (2008) 65 ACSR 661 par 67; Vinciguerra v MG Corrosion Consultants Pty Ltd [2010] FCA 763 par 54.

22 Par 175

23 Maher v Honeysett and Maher Electrical Contractors Pty Ltd supra par 33.

24 (2011) 82 ACSR 259 par 107; see also Re Wan Ze Property Development (Aust) Pty Ltd (2012) 90 ACSR 593 par 13.

25 Maher $v$ Honeysett and Maher Electrical Contractors Pty Ltd supra par 33. 
Having regard to the level of evidence required by the Australian courts to establish an honest belief is also instructive for the South African judiciary. An honest belief in Australian law may be satisfied on very little evidence. For instance, despite the plaintiff's admission in Lakshman $v$ Law Image ${ }^{26}$ that he had no evidence on which to ground his allegations of breach of fiduciary duty by a director of the company, the court nevertheless held that: ${ }^{27}$

"I am satisfied that the plaintiff has an honest belief that Raj has not acted in the best interests of the company and has in fact acted contrary to its interests and that there is some basis for that belief."

The general approach of the Australian courts is that an applicant is to be regarded as acting in good faith unless some factor or inference establishes lack of good faith. ${ }^{8}$ For instance, in BL and GY International Co Ltd $v$ Hypec Electronics Pty $L_{t d}{ }^{29}$ in making its finding that the applicant was in good faith, the court held that "[t]here are no indications that Mr Mead [the applicant] is acting otherwise than in good faith". Likewise in Braga $v$ Braga Consolidated Pty $\mathrm{Ltd}^{30}$ the court cursorily dealt with good faith by stating, "[as] to section $237(2)(b)$ [the statutory requirement of good faith] ... there is no reason to think that the applicant is not acting in good faith." The court in Brightwell $v$ RFB Holdings ${ }^{31}$ likewise tackled good faith by simply stating: "[a]s to [the] requirement [of good faith], there is no reason for doubting, on the evidence before me, that the plaintiffs are acting in good faith", while Charlton $v$ Baber $^{32}$ found that "[o]n the evidence, there is nothing calling in question Mr Charlton's [the applicant's] motives. I am satisfied that he is acting in good faith". It seems to be the general approach of the Australian courts that the applicant will be regarded to be acting in good faith if there is no evidence or inference establishing bad faith or calling into question the applicant's motives. ${ }^{33}$ It is submitted that this is the preferable approach to good faith that should be adopted in South African law. It should similarly be relatively easy to establish good faith for the purposes of section 165(5)(b)(i) of the South African Act, and the level of evidence that is required to prove good faith should generally be fairly low. This does not mean that the burden of proving of good faith is less than proof on a balance of probabilities, but merely that the level of evidence required to discharge this burden should as a general principle be quite low.

\footnotetext{
[2002] NSWSC 888 par 23.

Par 26.

28 BL and GY International Co Ltd v Hypec Electronics Pty Ltd [2001] NSWSC 705; Braga v Braga Consolidated Pty Ltd [2002] NSWSC 603.

29 BL and GY International Co Ltd v Hypec Electronics Pty Ltd supra par 89.

30 Supra par 6.

31 [2003] NSWSC 7 par 28.

32 [2003] NSWSC 745 par 44

33 See further eg, Herbert $v$ Redemption Investments Ltd [2002] QSC 340 par 30; Prendergast v DaimlerChrysler [2005] NSWSC 131 par 97; Isak Constructions v Faress [2003] NSWSC 784 par 13.
} 


\section{Proof of the absence of a collateral purpose}

Regarding the second element of good faith, namely that the applicant must not be seeking to bring the derivative action for a collateral or ulterior purpose, as submitted above, the onus of proof must rest on the applicant to prove the absence of a collateral purpose on his or her part in order to obtain the leave of the court for a derivative action - contrary to the dictum of the Supreme Court of Appeal in United Manganese. ${ }^{34}$

The aspect of collateral purpose requires the court to scrutinise the applicant's motivations and purposes in seeking leave to bring the derivative claim. The courts may from the evidence draw inferences about the motives and purposes of the applicant in seeking leave. ${ }^{35}$ Important considerations would include the applicant's financial interest or personal interest in the company, and his or her incentive or reasons for wanting to sue on behalf of the company. The self-interest of the applicant is a key consideration. ${ }^{36}$ The less the applicant's self-interest in the outcome of the matter, the greater should be the extent of the court's scrutiny of his or her good faith. It is important to distinguish between self-interest and a collateral purpose, as discussed further in Paragraph 3 of Part 1 of this article. An applicant's selfinterest in the derivative claim does not necessarily negate or destroy his or her good faith. On the contrary, the applicant who has self-interest and stands to gain some benefit from the success of the derivative action is more likely to be found to be acting without a collateral or ulterior purpose. ${ }^{37}$ The applicant who has nothing to gain by the success of the derivative action, no financial interest in the company nor any involvement in its management, should be subjected to closer scrutiny by the court insofar as his or her motives and purposes in bringing the derivative claim are concerned. It is submitted that as a broad guideline it should be fairly easy to establish good faith and the absence of a collateral purpose in the following circumstances: ${ }^{38}$

(i) where the application for leave to bring a derivative action is made by a current shareholder of the company with more than a token shareholding who proposes a derivative action to recover corporate property. In these cases the applicant's interest in the matter is that the value of his or her shares would increase if the derivative action were successful;

(ii) where the applicant is a current director or prescribed officer of the company. It should generally be easy to show that such an applicant

34 Par 11.

35 M F Cassim The New Derivative Action under the Companies Act: Guidelines for Judicial Discretion 46 53; Goozee v Graphic World Group Holdings Pty Ltd supra par 68; Cannon Street Pty Ltd v Karedis supra par 180; Maher v Honeysett and Maher Electrical Contractors Pty Ltd supra; Chapman v E-Sports Club Worldwide Ltd (2000) ACSR 462; Hassall v Speedy Gantry Hire Pty Ltd [2001] QSC 327.

36 See the decision of the court a quo in Mbethe $v$ United Manganese of Kalahari (Pty) Ltd 2016 (5) SA 414 (GJ) par 177 adopting the comments of M F Cassim 20133 SALJ 523.

37 See the decision of the court a quo in Mbethe $v$ United Manganese of Kalahari (Pty) Ltd 2016 (5) SA 414 (GJ) par 178 quoting with approval M F Cassim 20133 SALJ 523.

38 See eg, Maher v Honeysett supra par 35; Swansson v R A Pratt Properties Pty Ltd supra par 38; Magafas v Carantinos [2006] NSWSC 1459; M F Cassim The New Derivative Action under the Companies Act: Guidelines for Judicial Discretion 53. 
has a legitimate interest in the welfare and good management of the company itself;

(iii) where the applicant is a trade union or other employee representative representing employees of the company. Employees may generally be more familiar than shareholders with the affairs of the company and the improper practices of directors and corporate managers that are the subject matter of derivative litigation. Employees significantly have a definite interest in the welfare and proper management of the company, as corporate mismanagement and misconduct puts their jobs, their wages and their livelihood at risk.

The approach of the Australian courts lends support to the above submissions. In Australian law, it has been said to be "relatively easy" ${ }^{39}$ for a derivative litigant to prove the absence of a collateral purpose. "Relatively little" ${ }^{\prime 0}$ is required by the Australian courts to establish good faith and the absence of a collateral purpose in the first two circumstances ${ }^{41}$ listed above. $^{42}$ In these circumstances, the Australian judicial approach to the enquiry into collateral purpose seems to be that if there is nothing to suggest any collateral purpose of the applicant or any purpose other than obtaining redress for the company, this facilitates the drawing of an inference that there was no collateral purpose. In Maher $v$ Honeysett, ${ }^{43}$ for instance, the Supreme Court of New South Wales approached the enquiry into collateral purpose as follows:

"Significantly, Mr Honeysett [i.e. the applicant] is not a former but a current shareholder of HME, with much more than a token shareholding, and the derivative action seeks compensation for HME, and if successful will enhance the value of his shares in it. Accordingly, this is the type of case in which relatively little will be required to establish good faith. ... And while accepting completely [counsel's] reminder that it is for the applicant to prove criterion (b) [namely, the absence of a collateral purpose], the absence of any alternative hypothesis as to any "improper" collateral purpose of Mr Honeysett, in the context of the matters which I have mentioned, facilitates the drawing of that inference." [emphasis added]

Likewise, in Hannon $v$ Doyle, ${ }^{44}$ the court held:

"As to the second aspect [of good faith, i.e. the absence of a collateral purpose], there is nothing to suggest any interest or purpose of Mr Hannon [i.e. the applicant] other than the obtaining of appropriate redress for Holdings and Afro Capital. He is a $16 \%$ shareholder in Holdings which, in turn, owns $88 \%$ of the shares in Afro Capital. There is no reason to think that Mr Hannon has in view anything beyond the interests of those two companies and, of course, his own coinciding interest as a member of Holdings."

39 Swansson v R A Pratt Properties Pty Ltd supra par 38.

$40 \quad$ Maher $v$ Honeysett supra par 35.

41 The third circumstance listed above is not relevant in Australian law, since the Australian legislation - unlike the South African Act - does not give locus standi to employees or trade unions to bring a derivative action.

42 Swansson v R A Pratt Properties Pty Ltd supra par 38; Magafas v Carantinos supra; M F Cassim The New Derivative Action under the Companies Act: Guidelines for Judicial Discretion 53.

43 Maher $v$ Honeysett supra par 35-36.

44 Supra par 109. 
In contrast with the above circumstances, if the applicant in question has nothing obvious to gain directly from the success of the derivative action and little incentive to sue on behalf of the company, it is submitted that the court should scrutinise with particular care the purpose for which the derivative action is said to be brought. ${ }^{45}$ Such an applicant is more likely to be found to be motivated by a personal vendetta or a collateral purpose amounting to an abuse of the derivative action. It is further submitted that it should still be possible for an applicant to satisfy the requirement of good faith with neither a financial interest in the company nor any involvement in its management, but this ought to be more difficult to establish and may call for additional evidence to show good faith and the absence of a collateral purpose. ${ }^{46}$ As summed up in the Australian case of Maher $v$ Honeysett, ${ }^{47}$ "the onus of proving the good faith criterion might vary, depending upon the standing of the applicant". It is submitted that a test that may be useful in the South African context is whether as a current shareholder, director or representative of employees of the company, the applicant would suffer a real and substantive injury if a derivative action was not permitted, provided that the injury is dependent on or connected with the applicant's status as such shareholder or director or employee representative and the remedy afforded by the derivative action would reasonably redress the injury. ${ }^{48}$

Finally, the enquiry into whether the proposed action is "in the best interests of the company" in terms of the third leave criterion contained in section 165(5)(b)(iii) may shed light on the applicant's motives and purposes in seeking leave. If the proposed derivative action is not in the best interests of the company, the applicant's motives and purposes are likely to be suspect and the court may conclude that the applicant is driven by a collateral purpose and therefore lacks good faith. ${ }^{49}$

\section{A presumption of good faith?}

A brief discussion of the proof of good faith in Canadian law, as interpreted and applied by the Singapore courts is of interest. Good faith in Canadian law is a crucial requirement for the statutory derivative action, as in Australian and South African law. ${ }^{50}$ The onus of proof in Canadian law likewise is on the applicant ${ }^{51}$ to satisfy the court of his or her good faith on a

45 In Australian law see eg Swansson v R A Pratt Properties Pty Ltd supra par 38; Fiduciary Ltd v Morningstar Research Pty Limited supra.

46 See eg, Charlton v Baber supra; Goozee v Graphic World Group Holdings Pty Ltd supra par 68, Cannon Street Pty Ltd v Karedis supra par 180

47 Maher v Honeysett and Maher Electrical Contractors Pty Ltd supra par 29.

48 See eg, Chahwan v Euphoric Pty Ltd supra.

49 See further Par 3.1 of Part 1 of this article.

50 Canada Business Corporations Act, 1985, s 239(2)(b); see the decision of the court a quo in Mbethe v United Manganese of Kalahari (Pty) Ltd 2016 (5) SA 414 (GJ) par 154; M F Cassim The New Derivative Action under the Companies Act: Guidelines for Judicial Discretion 32-34.

51 Primex Investments Ltd v Northwest Sports Enterprises Ltd [1995] 13 BCLR (3d) 300 (SC); Discovery Enterprises Inc v Ebco Industries Ltd [1997] 40 BCLR (3d) 43 (SC); Lost Lake Properties Ltd v Sunshine Ridge Properties Ltd [2009] BCSC 938, 179 ACWS (3d) 1101 (BCSC). 
balance of probabilities. The typical approach of the Canadian courts to the demonstration of good faith is that:

"Good faith is said to exist where there is prima facie evidence that the complainant is acting with proper motives such as a reasonable belief in the merits of the claim. Good faith is a question of fact to be determined on the facts of each case. The typical approach by the Courts is not to attempt to define good faith but rather to analyse each set of facts for the existence of bad faith on the part of the applicant. If bad faith is found, then the requirement of good faith has not been met."

Several Canadian courts have adopted the approach that it will be presumed that an applicant is acting in good faith where there appears to be an arguable case unless there is evidence or some reason to believe that the applicant was motivated by a collateral or improper purpose. ${ }^{53}$ In Primex Investments Ltd $v$ Northwest Sports Enterprises $L t d{ }^{54}$ for instance, the court decided the issue of good faith as follows:

"[The applicant] has satisfied the onus of showing that it is acting in good faith.... [He] believes that Mr Griffiths has acted improperly and, if there were no substance behind the belief, one could conclude that he is pursuing a vendetta. However, as I conclude when dealing with the criteria under section 225(3)(c), there is an arguable case that Northwest [i.e. the company] has a claim against Mr Griffiths. [The applicant] cannot be said to be acting in bad faith because he wants to pursue what he genuinely considers to be a valid claim" [emphasis added].

It appears from the approach of the Ontario Court of Appeal in Richardson Greenshields of Canada Ltd $v$ Kalmacoff ${ }^{55}$ that the question of the legal merits of the proposed derivative action is an overarching consideration; it underlies all the criteria for a statutory derivative action, including the criterion of good faith. ${ }^{56}$

In reliance on the approach adopted in these Canadian cases, the Singapore High Court and Singapore Court of Appeal have ruled that the court is entitled to assume good faith on the part of an applicant who has a reasonable and legitimate claim unless proven otherwise. ${ }^{57}$ Notably, the Singapore statutory derivative action ${ }^{58}$ is largely modelled on the Canadian version $^{59}$ and has broad similarities with the Australian version. ${ }^{60}$ Section $216 \mathrm{~A}(3)$ of the Singapore Companies Act requires a complainant to satisfy the court as to three matters before the court will grant leave for a derivative action, one of which is that "the complainant is acting in good faith" in terms of section $216 \mathrm{~A}(3)(\mathrm{b})$. In reliance on the Canadian approach, the Singapore

52 Winfield $v$ Daniel [2004] AF No 37, 352 AR 82 (QB) par 16; $L$ and B Electric Ltd v Oickle [2006] NSJ No 119, 15 BLR $\left(4^{\text {th }}\right) 195$ (CA).

53 See eg, Primex Investments Ltd $v$ Northwest Sports Enterprises Ltd supra; Discovery Enterprises Inc v Ebco Industries Ltd supra; Richardson Greenshields v Kalmacoff (1995), 22 OR (3d) 577 (CA)

54 Supra par 32

55 Supra.

56 See also Discovery Enterprises Inc v Ebco Industries Ltd supra par 107.

57 See the cases discussed below.

58 S 216A of the Singapore Companies Act (Cap 50).

59 S 239 of the Canada Business Corporations Act, 1985.

60 S 236 and 237 of the Australian Corporations Act 2001 
High Court in Agus Irawan v Toh Teck Chye ${ }^{61}$ held that in the absence of any factors pointing to an applicant's lack of good faith, the court is entitled to:

"assume that every party who comes to Court with a reasonable and legitimate claim [is] acting in good faith - until proven otherwise."

According to Agus Irawan, an assumption of good faith on the part of an applicant arises where the applicant has a "reasonable and legitimate claim". The approach of the High Court in Agus Irawan was approved by the Singapore Court of Appeal in Pang Yong Hock $v$ PKS Contracts Services Pte $L t d{ }^{62}$ which found it to be "beyond reproach". The Singapore Supreme Court of Appeal stated further that: ${ }^{63}$

"The best way of demonstrating good faith is to show a legitimate claim, which the directors are unreasonably reluctant to pursue with the appropriate vigour or at all. Naturally, the parties opposing a section 216 A application will seek to show that the application is motivated by an ulterior purpose ... [I]f the opposing parties are able to show that ..., that may be sufficient for the court to find a lack of good faith on [the applicant's] part" [emphasis added].

The Singapore High Court in Fong Wai Lyn Carolyn v Airtrust (Singapore) Pte $L t d^{64}$ similarly applied a presumption of good faith.

In the context of South African law, both the High Court and the Supreme Court of Appeal in the United Manganese case declared that the South African courts will not apply a legal presumption of good faith even if an applicant has shown that the proposed derivative action appears to have legal merit and that it is in the best interests of the company. ${ }^{65}$ It is submitted, based on a modification of the judicial approaches in Canada and Singapore, that a useful guiding principle for the South African courts is that where the proposed derivative action appears to have merit and is in the best interests of the company it may generally be inferred that the applicant is acting in good faith, unless there are objective facts, circumstances or inferences to establish bad faith or that call into question the applicant's motives. $^{66}$ This is not to suggest that the South African courts should adopt a presumption of law in respect of good faith, nor is it suggested that the onus of proof of good faith should shift to the respondent who opposes a section 165(5) application. However, as a practical approach to determining whether the applicant is acting in good faith for the purposes of section 165(5)(b)(i) of the Act, the satisfaction by the applicant of the second and third criteria for leave, in the absence of any facts or circumstances to establish bad faith, should in most cases be sufficient for the South African courts to infer that the applicant is acting in good faith. To explain this further, if the proposed derivative action involves a serious question to be tried in terms of section

\footnotetext{
[2002] 1 SLR(R) 471 par 9.

[2004] SGCA 18 (SGCA) par 18-19.

Pang Yong Hock v PKS Contracts Services Pte Ltd supra par 20.

[2011] SGHC 88 (SGHC).

Mbethe $v$ United Manganese of Kalahari (Pty) Ltd 2017 (6) SA 409 (SCA) par 8; Mbethe $v$ United Manganese of Kalahari (Pty) Ltd 2016 (5) SA 414 (GJ) par 156, 172, 174.

66 See M F Cassim The New Derivative Action under the Companies Act: Guidelines for Judicial Discretion 52.
} 
165(5)(b)(ii) and thus has merit, then a court should be more inclined to conclude that the applicant has an "honest belief" that the company has a good cause of action with a reasonable prospect of success i.e. that the first aspect of good faith is satisfied. Furthermore, if the proposed derivative action is in the best interests of the company in terms of section 165(5)(b)(iii), a court should be more likely to infer that the applicant does not have a "collateral purpose" and is seeking to bring the derivative action to protect the interests of the company itself (rather than to secure his or her own personal purposes) i.e. that he or she satisfies the second aspect of good faith. The two enquiries into the merits of the case and the best interests of the company could shed light on the applicant's honesty, purpose and motivations in seeking leave, which lie at the heart of good faith - unless of course there are other objective facts, circumstances, evidence or inferences to establish bad faith or call into question the applicant's motives.

\section{CONCLUSION}

In order to obtain judicial leave to bring a derivative action in terms of section $165(5)(b)$ (i) of the Act, the onus of proof plainly rests on the applicant to satisfy the court, on a balance of probabilities, that he or she is acting in good faith. The proof of good faith undoubtedly presents difficulties, as it requires an enquiry into the subjective aspects of an applicant's state of mind. It may be particularly challenging for an applicant to positively prove that he or she had no collateral purpose. Notwithstanding these challenges, it is essential for the South African courts to categorically accept that the criterion of good faith contained in s 165(5)(b)(i) of the Act is a two-part enquiry that requires the applicant to satisfy two related elements; the applicant must prove not only that he or she has an honest belief that a good cause of action exists with a reasonable prospect of success (referred to as "honest belief"), but additionally that he or she has not brought the section 165 application for a collateral or ulterior purpose.

With regard to the first aspect of the good faith enquiry, namely an "honest belief", honesty is of course a largely subjective matter, but there are limits to the subjective test. The courts may draw inferences concerning an applicant's state of mind from the objective facts, circumstances and evidence. If there are no reasonable grounds for the applicant's belief, this may be the basis for finding that it was not in fact honestly held. It is submitted that a major step to showing an "honest belief" that the company has a good cause of action with a reasonable prospect of success for the purposes of section 165(5)(b)(i) is whether, in terms of section 165(5)(b)(ii), there is a serious question to be tried. Although the satisfaction of the second leave requirement in section 165(5)(b)(ii) will not be conclusive evidence that the applicant has an honest belief, it will be a major step towards proving it. There is no particular type of evidence and no particular means by which an applicant may prove his or her honest belief. A sworn statement of the applicant's good faith should usually carry little weight. Based on the general approach of the Australian courts, it is submitted that applicants should generally be able to satisfy the requirement of an honest belief quite easily and on relatively low evidence. This does not mean that 
the burden of proving of good faith is any less than proof on a balance of probabilities, but merely that the level of evidence required to discharge this burden should, in general, be quite low.

Regarding the second element of the good faith enquiry, namely the absence of a collateral or ulterior purpose, the courts may from the evidence draw inferences about the motives, intentions and purposes of the applicant in seeking leave. It is submitted, as supported by the Australian judicial approach, that it should be relatively easy for an applicant to establish the absence of a collateral purpose - depending on the particular applicant's standing, the applicant's financial interest or personal interest in the company, and the applicant's incentive or reason for wanting to sue on behalf of the company. Yet in circumstances where an applicant has no financial interest in the company, no involvement in its management and little other incentive or reason to sue on behalf of the company, the court should scrutinise more carefully the applicant's motives and the purposes for which the derivative action is said to be brought. Such an applicant may still be able to establish good faith, but in these cases, it ought to be more difficult and the courts may require additional evidence to show good faith. Notably, the enquiry into whether the proposed derivative action is "in the best interests of the company" for the purposes of the third leave criterion contained in section 165(5)(b)(iii) of the Act may cast some light on an applicant's motives and purposes in seeking leave.

It is submitted that a useful, practical approach for the courts in their determination of whether an applicant is acting in good faith is that where the proposed derivative action appears to have merit (i.e. there is a serious question to be tried) and the proposed derivative action is in the best interests of the company, this should generally be sufficient for the court to infer that the applicant is acting in good faith - unless there are objective facts, circumstances, evidence or inferences to establish bad faith or call into question the applicant's motives or purposes. The satisfaction by an applicant of the second and third criteria for leave under section 165(5)(b)(ii) and (iii) may shed light on the applicant's good faith, in view of the interplays and links among the three criteria for leave contained in section 165(5)(b)(i) - (iii). This is not to suggest that the South African courts should adopt an actual presumption of law in respect of good faith, nor is it suggested that the onus of proof of good faith should shift to the respondent who opposes a section 165(5) application. 